\title{
Comparative Religion and Anti-Religious Museums of Soviet Russia in the 1920s
}

\author{
Marianna Shakhnovich (D) \\ Department of Philosophy of Religion and Religious Studies, Institute of Philosophy, State Saint-Petersburg \\ University, Saint-Petersburg 190000, Russia; m.shakhnovich@spbu.ru
}

Received: 15 December 2019; Accepted: 17 January 2020; Published: 21 January 2020

\begin{abstract}
By the end of the 1920s, more than 100 anti-religious museums had been opened in the Soviet Union. In addition, anti-religious departments appeared in the exhibitions of many local historical museums. In Moscow, the Central Anti-Religious Museum was opened in the Cathedral of the Strastnoi Monastery. At that time, the first museum promoting a comparative and historical approach to the study and presentation of religious artifacts was opened in Petrograd in 1922. The formation of Museum of Comparative Religion was based on the conjunction of the activities of the Petrograd Excursion Institute, the Academy of Sciences, and the Ethnographic department of Petrograd University. In this paper, based on archival materials, we analyze the methodological principles of the formation of the exhibitions at the newly founded museum, along with its themes, structure, and selection of exhibits. The Museum of Comparative Religion had a very short life before it was transformed into the Leningrad anti-religious museum, but its principles were inherited by the Museum of the History of Religion, which was opened in 1932.
\end{abstract}

Keywords: comparative religion; anti-religious propaganda; Soviet Russia; museums; history of religion; cultural revolution

The purpose of this article is to highlight the problem of the conjunction of comparative religion and museum construction in the early Soviet era. Historical circumstances had developed such that the first museum exhibitions on the history of religion arose in Russia under conditions at the beginning of (and, then, in the heyday of) anti-religious propaganda, and the question of the degree of "scientificness" of particular exhibitions from the 1920s to the 1980s rests on the assessment of the degree of "science" and ideological commitment of any research on religion conducted during this period in Russia. To solve this complex issue, in our opinion, one should rely on the basis of the principles and methods of intellectual history, which considers its main task to be the study of intellectual activity and processes in the field of humanitarian and social knowledge in a sociocultural and historical context. In doing so, we rely on archival documents and publications from the 1920s and early 1930s. Without claiming to be a comprehensive solution to the problem, we shall try to show that, in the 1920s, the scholars of religion used comparative religion and anthropological approaches as their main methodological principles for creating exhibitions on religion; however, this academic position did not find support among left radicals and party ideologists.

In classical works on the history of European comparative religious studies, nothing has been said about its development in Russia (Sharpe 1975; Stroumsa 2010). The Rossica non leguntur rule applies to almost the entire history of Russian religious studies, from the 18th century through to the first half of the 20th century, with the exception of some research works that were written and published in German or English (Turaev 1895; Bogoraz 1907). Therefore, we ought to say a few words about the features of the Russian situation in comparative religion during the first quarter of the last century.

At the beginning of the 20th century, the academic study of religion appeared in Russia in the framework of Oriental studies (Tolz 2011), the history of antiquity (Zaborowski 2009), and 
ethnography (Kan 2009). Unlike other European countries, where separate departments for the history of religions appeared in universities in the first half of the 19th century, the teaching of any religious discipline in Russian universities could only be carried out by theologians who were educated at special theological educational institutions (Shevzov 2017). It is important that, in recent years, some interesting publications highlighting the activities of Orthodox missionary priests in the study of popular religiosity and traditional religions have appeared (Tolz 2011; Chumakova 2017; Matochkina and Stetskevich 2018).

However, in contrast to a number of European countries, at that time spiritual censorship existed in Russia, under which all publications on religious and Church issues fell. It is important to note that, even in the first years of the last century, it was extremely difficult for researchers to overcome the existing censorship limitations in the study of the history and anthropology of religions. While, within the framework of the officially supported discourse, not only frankly weak academic publications were published, but also works that spread false ideas about the religions of national minorities, causing enmity and hatred towards them (Istoriia Religiovedeniia 2018, pp. 9-10).

Through the 19th century and into the beginning of 20th century, great restrictions were put over those scholars who sought to conduct research on the history of Christianity and Biblical studies using historical and cultural methodologies which, by then, were widespread in many universities in Europe. The very idea of a comparative study of all religions was strongly criticized. According to the points of view of the state, Church, and the majority of the academic community, relying on the confessional tradition, the only purpose of the history of religions was propaedeutic to theology, considering the comparative study of religions as the path to conscious Christian faith. In 1902, a professor of the Moscow Theological Academy, Sergei Glagolev, wrote that studying the history of religion does not have a research task: "We mean to use the history of religions as an apologetic argument" (Glagolev 1902, p. 13). Even those scholars who believed that science did not contradict religion, that it was capable to open the beauty of the world to human beings and, thus, bring a person to God, nevertheless denied the possibility of using rationalistic methods in studying the history of spiritual culture; not to mention the possibility of using it for studying the sacred texts, which they proposed to interpret symbolically. The possibility of the limited use of historical methods in theological works after the adoption of the new charter of theological academies in 1869 caused a peculiar "historical and theological revolution" in the higher spiritual schools of Russia (Sukhova 2013, pp. 135-50).

The comparative method gradually gained an increasing number of supporters; moreover, its application to the history of culture aroused great public interest. At the beginning of the last century, such an approach was met with harsh criticism from those authors who interpreted the history of religion as an apologetic narrative. For example, Prince Sergei Trubetskoi, the rector of Moscow University and famous philosopher, was forced to write a large article in response to criticism for his works considering Christianity in the context of the history of other religions in classical antiquity. Trubetskoi wrote that he was accused of "bringing Christianity 'from the ancient pagan religions and philosophies', the teachings on the incarnation of the Son of God 'from pagan myths about the conversion of gods', the cult of Our Lady - 'from honoring Aphrodite or Venus', church worship—from pagan worship, sacraments-from the mysteries, icons_from the idols." Trubetskoi asserted: "In vain we think to protect Christianity, making it stand out from history. It is a shame to the historian who, in the field of religion, deviates from his direct, lofty task-to understand human reality in its past" (Trubetskoi 1897, pp. 57-58).

At the beginning of the 20th century, it became clear that the use of comparative methodologies in the study of religion required solving the following theoretical problems: Is comparative religion a science that considers all religions, including so called "primitive" religions, or should it be limited to the so-called "historical religions" with written traditions? Is comparative religion possible in terms of the religious studies of civilizations and cultures, regarding religion as one of the most important factors that determines the isolation of a certain culture? Is it possible to consider the 
problem of the formation of faith in God and the formation of the idea of God in the context of universal linear-progressive evolution? In 1900, Lev Sternberg, who began studying the religions of the indigenous peoples of the Far East during his exile for revolutionary activities, singled out the main methodological principle that distinguished Religionsgeschichte (mainly studying the "higher" religions) from Religionswissenschaft (a comparative study of religions by an anthropological school), to which he adjoined himself. He wrote: "Between the primitive imperatives of primitive cultures and the grandiose ethical teachings of higher religions, the difference is only in the stages of social and mental development" (Shternberg 1900, pp. 323-28).

One researcher who attempted to apply anthropological methods to the analysis of historical religions, considering them in the general context of the evolution of spiritual culture, was Yevgenii Kagarov. He sought to combine the achievements of the cultural-historical school of the study of ancient antiquities with the latest methods of comparative study of cultures. Kagarov believed that, on the basis of a comparative study, it was possible to draw a conclusion about the evolution of religious beliefs, and that "Christianity is essentially a synthesis of all previous religious and historical development, and that it included numerous Egyptian, Babylonian, Asia Minor, Persian and Greek elements" (Kagarov 1934, pp. 1-3; Shakhnovich 2017).

As early as in 1919, courses on the comparative study of religions and the history of world religions were included in the curricula of the Faculty of Social Sciences of the First University of Petrograd (formerly the Imperial Petersburg University). In the process of reorganization of the Faculty of History and Philology and the Faculty of Oriental Languages, their deans-professors Sergei Zhebelev and Nikolai Marr-explained the need to teach the history of religion in a special paper, saying that "in such a multi-religious country as Russia, in a country, whose people still exist in the power of enrooted superstitions, the scientific disclosure and scientific coverage of religious phenomena based on independent criticism is of tremendous national importance" (Zhebelev and Marr 1919, p. 10).

In 1922, Nikolai Nikolski, a historian of the ancient world and a biblical scholar, characterized religious studies as a young scientific discipline which emerged at the end of the 19th century, has a great future, and is designed to solve the deep problems of the history of culture in his presentation "Religion as a Subject of Science". He emphasized that, for the non-stop development of the science of religion, the same freedom "from any incoming presumption" is needed in scope and setting, as for any other science. The historian of religion should not only have a formal right, but also a factual right to be completely free from any reservations to engage in their own research. He stated that the revolution finally created the conditions for the development of this science, that the history of religion could be freely taught at universities where departments of the history of religion are created, and those researchers who studied the history of religion privately were able to prepare students without any pressure from theology (Nikolski 1923, pp. 33-34). The early post-revolutionary situation gave some hope to these ideas.

The resolution of the XII Party Congress "On the Formulation of Anti-Religious Agitation and Propaganda" (April 1923), noted the need to study the history of religion, as well as the forms and methods of atheistic propaganda. The corresponding propaganda structures began to develop various forms of anti-religious activities, including visual agitation, firstly with the help of printed materials and posters and, then, with museum materials. It is important to note that the idea of using so-called "visual aids" in the system of propaganda during this period was literally worn in the air. For example, Boris Kandidov, the organizer and first director of the Central Anti-Religious Museum in Moscow, wrote in his memoirs, 'The Way of Struggle': "The experience in enlightening and mass anti-religious work in 1922 and in 1923 led me to the conclusion of the usefulness of a visual display system. Lectures, reports, conversations, all kinds of performances gave good results, but it was necessary to show the working and peasant audience the correctness of our point of view convincingly and vividly on the documents, pictures, on various exhibits in artistic form" (Kandidov 2012, p. 264).

In March 1922, in the journal 'Under the Banner of Marxism', an article by V. Lenin, 'On the Importance of Militant Materialism', was published. Usually, when following Soviet historiography, 
attention is paid to the fact that this article marked the beginning of a new stage of political work in the field of religion related to the transition from anti-religious agitation to anti-religious propaganda. However, the repression of believers in the period of "collectivization" (state policy on the forced creation of collective farms) in the late 1920s through the beginning of the 1930s obscures the fact that the article was written during the short period of the "new economic policy", when the desire to overcome the systemic crisis associated with the revolution and civil war forced the government to allow some economic freedom. This period in the religious sphere, according to Gregory Freeze, was the period of "laicization of the Church" (Freeze 2012, p. 88); when, on one hand, Orthodox parishes gained a great deal of independence and, on the other hand, thanks to the removal of previous legal restrictions, the number of adherents to the so-called "Russian sects" and Protestants significantly increased. The article proclaimed "union with bourgeois science" in the field of religious studies ("union with the Drewses" as Lenin put it, referring to the German historian Arthur Drews). Lenin also pointed to writings on the religion by the philosophers of the French Enlightenment, who wrote vividly and clearly. That alliance, which implied reliance on a comparative historical and critical method in relation to religion, was announced precisely on the pages of that article, which was called the "philosophical testament" of Lenin. In order to form a conscious attitude towards religious issues among the uneducated people, the boring and dry retelling of Marxism (which, as Lenin wrote, prevailed at that time in propaganda literature and which often distorted Marxism) was not enough. Of course, Lenin did not disregard the Marxist sociological approach to the political role of religion as an institution but, in speaking about the role of religion in society, above all, he called for reliance on the modern science of religion.

The regiment of vulgar sociological views was very heavy in the religious studies of the 1920s and 1930s in Soviet Russia. In a majority of published texts, the point of view that religion in society depended on the interests of certain social groups and classes, and was linked to their political and ideological struggles, prevailed. However, the comparative method in the analysis of religion had already been quite well tested over decades in the development of the European science of religion and gradually became more and more popular, especially in connection with the fact that the works of James Frazer and some other scholars of religions (Frazer 1928, 1931; Proiskhozhdenie Religii 1932; Taylor 1939) were translated into Russian and published in great numbers. It should be noted that, in the first quarter of the 20th century, the works of the French scholar Salomon Reinach were very popular in Russia, as well. Reinach's book entitled 'Orpheus: A General History of Religions' was published after the revolution in 1919 with a rather significant circulation. In this book, he wrote about the importance of comparative religious studies and the history of religion: "Between the many tasks that lie in the form of duties in science, one of the most important is to compile the history of religions, establish their origin and explain their changing destinies. This is a very fruitful scientific work, which, one might say, began only yesterday. The real founders of the science of religion, Mannhardt, Robertson Smith, Max Muller, died no more than a few years ago, and teaching the history of religion at different universities is still in its infancy. But the need for such a story begins to be felt everywhere, society treats it with the greatest interest, and one might think that the 20th century will not fail to encourage research that aims not only to elevate and educate, but also to free the human mind from centuries of shackles" (Reinach 1919, p. 48). These ideas found their supporters in Russia.

By the mid-1920s, there were two groups inside the Russian academic community, with opposite views on the nature and sense of religious studies: one group explored the opportunity to undertake research without clerical censorship, wanted to study religion using different methodological approaches (including Marxism), and understood the expression "critique of religion", in the philosophical sense, as a historical and sociological analysis. The majority of them did not deny the Marxist idea of the gradual disappearance of religion in a secularized world. The other group-left political radicals-sought only to expose religion, looking for evidence of possible exposure. This same opposition can be observed in the sphere of the new museums constructed at that time.

The period of the 1920s to 1930s was the period of the Soviet cultural revolution, the task of which was to create a "new man", free from religion. This led to an appeal to the philosophy of 
Enlightenment, which implied faith in progress and in the human reason, due to the emancipation of which a rejection of religion might appear. The idea that museum activity should be put on scientific grounds fully corresponded to the spirit of the proclaimed revolutionary renewal of culture. It meant that the actual scientific and theoretic principles of the science of religion were considered to be the main principles of the exhibiting of religious artifacts. Religion was considered to be a cultural fact. The comparative approach, based on the theory of the evolution of religion, became very popular. That situation was perceived, by part of the academic community, as an opportunity to preserve artifacts of religious cultures in museums in order to save them from destruction, to study them, and even to present them to the public in exhibitions. Edward Tylor's theory of "survival", proclaimed in his book 'Primitive Culture', was very close to the Marxist idea of future disappearance of religion as a relic of the past. Evolutionism supposes that the traces of previous stages of development are preserved in following cultures, in a special way, and that one can find traces of the past in "survival" elements. These ideas were widely used, together with comparative methodology, both in research and in newly founded museums.

The very use of the comparative method in exhibiting the items of so-called "primitive religions" and "higher religions", first of all, in Christianity, may be perceived as the profaning of sacred Christian objects and Christianity itself as a religion. The comparison was intended to show, from one side, the origins of Christian beliefs and rituals and, on the other, to indicate that there was nothing special and miraculous in them, since they were similar to the beliefs and rituals of other religions.

From the mid-1920s, anti-religious exhibitions began to be created throughout the country, mainly on the basis of local history museums; however, from the end of 1928, with the 1929th special ordinance "On Religious Buildings", this particular practice became widespread on the premises of former temples and monasteries. By the end of the 1920s and the beginning of the 1930s, more than 100 anti-religious museums had been created, many of them opened on the territory of monasteries, and often in the premises of churches (Kandidov 1929; Posternak 2006).

From 1919 to 1925, more than 150 monasteries and temples were "museumified"-turned into historical, cultural, or church museums. However, the situation changed after the mid-1920s: Temples and monasteries lost their museum status, which led either to their physical destruction or to their turning into warehouses, factories, educational institutions, prisons, and so on (Kaulen 2005, pp. 29-33; Kelly 2016). During this period, the creation on the premises of monasteries and temples of anti-religious museums, paradoxically as it sounds now, contributed to their preservation.

In addition, anti-religious departments appeared in many local history and historical museums. In 1931, a resolution of the board of the People's Commissariat for Education "On Anti-Religious Museum Buildings" was published, according to which all museums, without exception and regardless of their profile, were required to carry out anti-religious work. In Moscow, the Central Anti-Religious Museum was opened in the Cathedral of the Strastnoi (Passions) Monastery in 1929. By governmental decree, in 1933, it was recognized as an all-Union scientific and methodological center of anti-religious work in museums. Most anti-religious museums did not have educated staff or a sufficient number of exhibits. Boris Kandidov explained how, in 1923, he created his first anti-religious exhibition in the Tambov Provincial Party Club, using posters, photographs, and a "dried baby" - a mummified corpse obtained from the Moscow morgue-and how he tried to "improve" the exhibition of the local museum with objects of religious art (Kandidov 2012, p. 265). Using available documents, photographs, posters, leaflets, and newspapers, local anti-religious museums denounced the union of the church and the autocratic monarchy, reducing the exposition and propaganda work mainly to criticism of the Russian Orthodox Church which, in the pre-revolutionary Russian state, was closely associated with the royal power.

The first museum promoting a comparative historical approach to the study and presentation of religious artifacts was started in Petrograd in 1922. It had educational aims. The formation of a new "Museum of Comparative Religion" was based on the conjugation of the activities of the Petrograd Excursion Institute, institutions of the Academy of Sciences, and the ethnographic department of 
Petrograd University. Already by the beginning of December 1922, the structural plan for the exhibition and a list of alleged exhibits, including both original artifacts and copies to be ordered (or, as it was said, "models"), were prepared. The plan was so voluminous and well-developed, and the list of exhibits was so long, that, combined, it did not represent the plan of a temporary exhibition but, instead, the plan of the museum for the comparative study of religions (or the museum of the history of religions), including the development of not only "primitive" and ancient polytheistic religions, but also world monotheistic religions. The construction of the exhibition was based on an evolutionary anthropological approach and comparative methodologies. It is impossible to detect even any hints of Marxist historical materialism in the structure of the museum. The authors of the plan did not set the task of exposing religion; they tried to show the diversity of religions as a variety of answers to the same questions that differed only in the stage of development of the society. Such a project could only be prepared if its authors knew perfectly not only the history of religion, but were also deeply aware of what was stored in Petrograd museums, primarily in the Hermitage and the Museum of Anthropology and Ethnography.

A structural plan and a list of exhibits, accompanied by a letter from the Petrograd Provincial Department of Political Education (Narpolitprosvet), were sent to the secretariat of the Central Committee of the RCP (Bolshevik) in Moscow, on 18 December 1922, for approval by Emelian Yaroslavski. It is important to note that he was not yet the leader of the League of Militant Godless, which was created three years later. The letter to the Secretariat of the Central Committee on the creation of an exhibition on the comparative study of religions was signed by Emma Rautenberg-Krasnukha, Chairman of the Commission for its organization. She was the director of the Excursion Institute of the Provincial Department of Public Education. The Museum of Comparative Studies of Religions in Petrograd was opened in 1923, at 13 Belinski St., as the part of the Excursion Foundation of the Provincial Department of Public Education. The documents testify the creation of the following sections of the exhibition: Souls, spirits, and afterlife; deification of fire; deification of animals, plants, stones, etc.; ancestral idolization; idolization of the host spirits; astral cult; the gods of higher polytheism; representatives of God-manhood; mediators between gods and people (shamans, priests, etc.); altars and temples; religious ceremonies (sacrifices, prayers, votism); holidays and mysteries; religious music; receptions of magic and sorcery; ethics and religion; religious symbolism; pagan experiences in monotheistic religions; pagan experiences in the European peasantry; monotheistic religions; and so on.

Among the exhibits, we mention the Siberian ones: Chukchi drawings on the theme of cosmogony and the astral cult (the sea gods Keretkun and Sedna, Raven-creator, the Sun, the Moon, the Dawn, Universe: underground and aboveground); images of Tungus (Evenk) spirits and deities (10 models); Tungus shaman (1 figure); shaman masks; images of birds and other shaman spirits (10 models); images of the spirits of diseases (6 figures); shaman's rite (5 photos); ritual treatment ( 3 models); shaman tree (model); Oroch deities and their spirits (5 models). There were also materials from South and North America, Australia, Oceania, and Africa, reflecting the religion of ancient Greece and Rome, Buddhism (types of Buddha in painting and sculpture; bodhisattvas in different interpretations; and so on), and Islam (drawings and photographs presenting the burial monuments of the saints; the feast of Hussein; images of mosques; dervishes) (Spisok eksponatov 1922, pp. 1-1a).

The Museum of the Comparative Study of Religion has undergone a number of reorganizations. In October 1924, the Museum was merged with the Anti-Religious Exhibition at the Nadejda Krupskaya Institute of Political Education, as "it did not correspond to the practice of anti-religious propaganda" (El'iashevich 1926, p. 52). As a result, the Museum of Anti-Religious Propaganda appeared, which was no longer subordinate to the Department of Public Education but was, instead, a part of the Political Education system. With this reorganization, the museum lost its academic character step-by-step and gradually turned into a museum adapted, not so much for education in the field of comparative religion but instead for propaganda against religion. The museum received a broad public interest. The popularity of such museums has surprised modern researchers (Husband 2000, p. XI), who have 
argued that the majority of the population sought to conform to an atheist state for conformist reasons; not supporting, but not opposing, the anti-religious campaign. From October 1924 to March 1925, 142 excursions were carried out in the museum; there were 2,455 excursionists: of these, 780 were workers, 1005 were students, 269 were military, and 401 others (El'iashevich 1926, p. 53).

In 1930, the Museum was transferred to St. Isaac's Cathedral and became the Leningrad State Anti-Religious Museum of the Leningrad Branch of the League of the Militant Godless. On the 12th of April, 1931, the Foucault pendulum was opened under the dome of St. Isaac's Cathedral, which was supposed to demonstrate the rotation of the Earth around the Sun. The Anti-Religious Museum at St. Isaac's was closed in 1941, but the Foucault pendulum remained there until 1986.

In 1929, in connection with the beginning of the Stalin era of the "Great turn" (i.e., the forced modernization of the country to industrialization and collectivization), a change in state policy in the field of religion took place. On 8 April 1929, the Decisions of the All-Russian Central Executive Committee and the Council of People's Commissars of the Russian Soviet Federative Socialist Republic "On Religious Associations" were adopted, which prohibited any educational, cultural, or social work by religious associations; their activity was limited only to meeting religious needs, which meant worship. From 1929, the regime began to direct its anti-religious policy not so much against the Church, as a social institution historically associated with the monarchical power and the clergy as its pillars, but also against ordinary active believers; this primarily affected the so-called sectarians.

In the same period, a sharp criticism of "flirting with religion" began; it touched those historians and ethnographers who were involved in museum construction. In early December 1930, the First All-Russian Museum Congress was held in Moscow. One of the active participants in the creation of the Anti-Religious Museum in St. Isaac's Cathedral, Sergei Lebedianski, speaking at this congress, said: "In Leningrad, the main exhibition serving all anti-religious work, recently opened in the premises of the Winter Palace, is a purely cultural exhibition. This exhibition is rather on the history of religion, and the history of religion is presented on an ethnographic basis, and the conclusion that an excursionist can make after viewing the exhibition is as follows: each people and each group had their own gods. This practice requires categorical condemnation, because it gives only elements of culturalism and does not even give a Marxist view, which leads to a blurring of the main content of anti-religious work and its political narrowness at the moment" (Trudy Pervogo 1932, p. 124). Arto Luukkanen wrote in some detail about the struggle of left anti-religious radicals with "culturalism" as a "bourgeois" attitude towards religion, in his book 'The Party of Unbelief: The Religious Policy of the Bolshevik Party 1917-1929' (Luukkanen 1994, pp. 224-37).

Studying the history of the science of religion in the Soviet Union, we constantly find documented evidence of the struggle between the two approaches in understanding the very content of the goals and objectives of research and educational work in the field of religion: the "cultural approach", based on academic principles, and the "propagandistic approach", based on the political reasons of the limitations in the religious sphere. Such opposition a historian of the religious studies may find in the 1920s, the 1930s, and the 1970s (Smolkin 2018, pp. 145-56).

The sharply critical remark concerning the cultural (i.e., comparative and anthropological) methodology of the "recent exhibition" was directed against the Anti-Religious Exhibition, created under the supervision of the anthropologist Vladimir Bogoraz (Mikhailova 2004, pp. 95-136; Arziutov and Vakhtin 2016, pp. 101-8; Bogoraz 2019), by the staff of the Hermitage Museum and the Museum of Anthropology and Ethnography of the Academy of Sciences, which opened on 15 April 1930 on the premises of the Winter Palace and dedicated to the fifth anniversary of the Union of Militant Atheists. It was very popular and, until the end of 1930, it was visited by about 20,000 people (Shakhnovich and Chumakova 2014, p. 25).

That exhibition was called anti-religious, but was an exhibition on the history of world religions, built on the basis of a comparative historical principle. The author of the guidebook for the exhibition, Yevgenii Kagarov, pointed out that the exhibition reflected a certain view: that the history of religions is a comparative study of religious ideas, beliefs, and rituals, based on an evolutionary approach; thus, 
socio-economic historical practice had also been taken into account. The selection of exhibits presented early forms of religion, particularly of Buddhism, Judaism, Christianity, and Islam; they contributed, in his opinion, to the identification the same functions of religious practice during various historical periods, demonstrated the unity of religious consciousness, and showed the evolution of religious beliefs and worship. One of the members of the working group for creation of the exhibition later wrote: "Bogoraz widely used the comparative method. For example, above the statue of Zeus an image of Savaoph, similar to Zeus was hung, the icon of the three-faced Jesus Christ was juxtaposed with the figure of the three-headed Shiva" (Shakhnovich 1958, p. 412).

In 1929, speaking at the Second Congress of the League of the Militant Godless, Bogoraz talked about creating exhibitions on the history of religion, saying that the principles of cultural evolutionism and the comparative method were the most industrial of all other approaches: "We will reveal on the museum material what is the religion of the primitive collective stage, what is the religion of hunting, the religion of cattle breeding, the religion of agriculture, and the new religion of a more industrial type. We will trace the evolution of the material shrines from amulets, from small religious items to larger fetishes, to icons and statues, from a simple prayer to a church, from witches to shamans, to priests and clergy." (Stenograficheskiu Otchet 1930, p. 232). Three years later, Bogoraz founded the Museum of the History of Religion of the Academy of Sciences, based on those principles. Crispin Paine made a mistake, in arguing that "in 1930 he founded the League of the Militant Godless, and two years later the Leningrad Museum of the History of Religion and Atheism" (Paine 2009, p. 69), and that he supported a Marxist understanding of history. Bogoraz did not create the League of the Militant Godless; that was Emelian Yaroslavski (Peris 1998). Bogoraz was a supporter of positivism, not a Marxist, and a critic of Bolshevism which he considered a special form of religion (Shakhnovich 2018). The addition "and atheism" in the name of the museum appeared almost 20 years after his death, in 1954, during the Khrushchev persecution of religion (Shakhnovich 2016, p. 430).

The Museum of the History of Religion was founded as a research institution for the multidisciplinary study of religion as a complex social and historical phenomenon. This included research into the evolution of religious ideas and faiths, the position of religion in the spiritual culture of various eras, the psychological aspects of religious belief, religious social movements, processes of secularization, religious art, and other topics. Although the word "history" was in the name of the museum, the approach to exhibiting objects was based on anthropological principles requiring reflection on everyday life. The comparative approach lay at the heart of the principles of the museum's foundation.

The Museum of the History of Religion has survived all museums one way or another connected with the study and criticism of religion created in the Soviet Union. Different authorities have tried to close it many times during its more than 80 years, but it has resisted to the present. The answer to this success, in our opinion, lies in the fact that, in the most diverse political and ideological circumstances, the museum tries to maintain the line of academic religious studies, inheriting the traditions of its founders closely associated with the St. Petersburg school of religious studies. Constantly balancing between the political demands of the moment and the academic approach, the museum seeks to rely primarily on academic methods and be guided by cultural and educational goals. It was in the 1920s that these foundations were laid, which made it possible to combine historical, philological, and anthropological methods, although not without a significant share of reductionism. However, it must be recognized that the comparative study of religion itself has significantly transformed in this direction over the past hundred years, enriching itself not only with the new ideas of the humanities and social sciences, but also with the achievements of the cognitive and natural sciences.

Funding: This research was funded by Russian Science Foundation, grant number 16-18-10083.

Conflicts of Interest: The author declares no conflict of interest. 


\section{References}

Arziutov, Dmitrii, and Nikolai Vakhtin. 2016. Vmesto vvedeni'a. K 150-leti'u V.G. Bogoraza. Antropologicheskiu Forum 29: 101-8. (In Russian).

Bogoraz, Voldemar. 1907. The Chukchee Religion. In Publications of the Jessup North Pacific Expedition, Vol. VII. Memoir of the American Museum of Natural History. Leiden: Brill, New York: Stechert, vol. 11, pp. 277-536.

Bogoraz, Vladimir. 2019. Evolyutsi'a Relizgioznyh Verovaniǔ. Kurs Lekciǔ (1927-1928 gg.). Edited by Marianna Shakhnovich. Saint Petersburg: Isdatel'stvo Sankt-Peterburgskogo universiteta. (In Russian)

Chumakova, Tatiana. 2017. Pravoslavnye Sviashennosluzhiteli 19-Pervoŭ Chetverti 20 Veka Kak Issledovateli Religii. Sviateishiı̌ Sinod v Istorii Rossiiskoŭ Gosudarstvennosti. Sbornik Materialov Vserossiiǔskoŭ Nauchnoŭ Konferentsii s Mezhdunarodnym Uchastiem. Edited by Sergei Firsov and Pavel Fedorov. Saint-Petersburg: Prezidentskaia biblioteka, pp. 334-50. (In Russian)

El'iashevich, Iosif. 1926. Antireligioznaia propaganda v Leningrade (1924-1925 gg.). Antireligioznik 5: 52-55. (In Russian).

Frazer, James. 1928. Zolotaia Vetv'. Moscow: Ateist. (In Russian)

Frazer, James. 1931. Zolotaia Vetv'. Moscow: Moskovskiŭ Rabochiǔ. (In Russian)

Freeze, Gregory. 2012. Vsia vlast' prihodam: vozrozhdenie pravoslaviya v 1920-e gody. Gosudarstvo Religia $i$ Tserkov' v Rossii i za Rubejom 3-4: 86-105. (In Russian).

Glagolev, Sergei. 1902. Ocherki Istorii Religiŭ. Ch. I: Religii Drevnel̆shih kul-Turnyh Narodov. Sergiev Posad: Typografia Sviato-Troitskoi Lavry. (In Russian)

Husband, William. 2000. "Godless Communists": Atheism and Society in Soviet Russia. DeKalb: Northern Illinois University Press.

Istoriia Religiovedeniia. 2018. Istoriia Religiovedeniia i Intellektualnaia Istoriia Rossii 19-Pervoi Poloviny 20 Veka. Arhivnye Materialy i Issledovaniia. Edited by Marianna Shakhnovich and Ekaterina Teriukova. Saint Petersburg: Isdatel'stvo Sankt-Peterburgskogo universiteta. (In Russian)

Kagarov, Evgenii. 1934. Vystuplenie. Saint-Petersburg: Russian National Library. Manuscript Department (OR $R N B$ ), fund 324, file 715. Typescript. (In Russian)

Kan, Sergei. 2009. Lev Shternberg. Anthropologist, Russian Socialist, Jewish Activist. Lincoln: University of Nebraska Press.

Kandidov, Boris. 1929. Monastyri-Muzei i Antireligioznaia Propaganda. Moscow: Bezbojnik. (In Russian)

Kandidov, Boris. 2012. Put' bor'by. In Sovetskoe Gosudarstvo i Religiia. 1918-1938 gg. Dokumenty iz Arhiva Gosudarstvennogo Muzeia Istorii Religii. Edited by Yevgenii Luchshev. St. Petersburg: Calamos. (In Russian)

Kaulen, Maria. 2005. Muzei-Hramy i Muzei-Monastyri: Katalog-Spravochnik. Moscow: Ripol klassik. (In Russian)

Kelly, Catriona. 2016. Socialist Churches: Radical Secularization and the Preservation of the Past, 1918-1988. DeKalb: Northern Illinois University Press.

Luukkanen, Arto. 1994. The Party of Unbelief: The Religious Policy of the Bolshevik Party 1917-1929. Helsinki: Studia Historica 48.

Matochkina, Anna, and Mihail Stetskevich. 2018. Stanovlenie rossiǔskogo islamovedeniia mezhdu konfessionalizmom i nauchnoŭ obektivnost'iu (vtoraia polovina 19-nachalo 20 v.). Gosudarstvo Religiia Tserkov $v$ Rossii i za Rubezhom 36: 82-106. (In Russian).

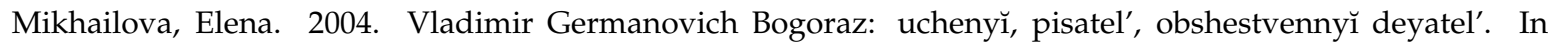
Vydaiushchiesia Otechestvennye Etnologi i Antropologi 20 Veka. Moscow: Nauka, pp. 95-136. (In Russian)

Nikolski, Nikolai. 1923. Religia Kak Predmet Nauki. Minsk: Beltrestpechat'. (In Russian)

Paine, Crispin. 2009. Militant Atheist Objects: Anti-Religion Museums in the Soviet Union. Present Pasts 1: 61-76. [CrossRef]

Peris, Daniel. 1998. Storming the Heavens: The Soviet League of the Militant Godless. Ithaca: Cornell University Press. Posternak, Ol'ga. 2006. Muzeinaia Politika Rossii i sud'ba Religioznogo Kul'turnogo Naslediia v 1920-1930-kh gg. diss. Kandidatskaya dissertatsia. Typescript. Moscow: Moskovskii gosudarstvennyi universitet. (In Russian)

Proiskhozhdenie Religii. 1932. Proiskhozhdenie Religii v Ponimanii Burzhuaznyh Uchenyh. Sbornik Statě̆. Edited by Alexander Lukachevski. Moscow: Moskovskiǔ Rabochir. (In Russian)

Reinach, Salomon. 1919. Orfěr. Vseobshchayia Istoriia Religii. Moscow: Fakel. (In Russian)

Shakhnovich, Mikhail. 1958. 25-letie Muzeŭ istorii religii i ateizma. Voprosy Istorii Religii i Ateizma 5: 410-24. (In Russian). 
Shakhnovich, Marianna. 2016. The Study of Religion in Russia. The Foundation of the Museum of the History of Religion. In Contemporary Views on Comparative Religion. In Celebration of Tim Jensen's 65th Birthday. Edited by Peter Antes, Armin Geertz and Mark Rothstein. Sheffield and Bristol: Equinox Publishing Ltd., pp. 425-37.

Shakhnovich, Marianna. 2017. Yevgenii Kagarov i Muzeŭ istorii religii Akademii nauk SSSR. Vestnik SPbGU. Filosofiia i Konfliktologiia 33: 571-81. (In Russian).

Shakhnovich, Marianna. 2018. V. G. Bogoraz o religii i bol'shevizme. Vestnik SPbGU. Filosofiia i Konfliktologiia 34: 441-53. (In Russian).

Shakhnovich, Marianna, and Tatiana Chumakova. 2014. Muzĕ̌ Istorii religii Akademii Nauk SSSR i Rossiǔskoe Religiovedenie (1932-1961). St. Petersburg: Nauka. (In Russian)

Sharpe, Eric J. 1975. Comparative Religion: A History. London: Duckworth.

Shevzov, Vera. 2017. Thoughts from Orthodoxy's Modern Past: Theology, Religion, and the University in Russia (Late Nineteenth to Early Twentieth Centuries). In Eastern Orthodox Christianity and American Higher Education: Theological, Historical, and Contemporary Reflections. Edited by Ann Mitsakos Bezzerides and Elisabeth Prodromou. Notre Dame: University of Notre Dame Press, pp. 167-98.

Shternberg, Lev. 1900. Sravnitel'noe izuchenie religil. Entsiklopedicheskiy̌ slovar' Brokgauza i Efrona 31: 323-28. (In Russian).

Smolkin, Victoria. 2018. A Sacred Space is Never Empty: A History of Soviet Atheism. Princeton and Oxford: Princeton University Press.

Spisok eksponatov. 1922. Spisok eksponatov Vystavki po sravnitel'nomuizucheniiu religii. Moscow: Russian State Archive of Social and Political History (RGASPI). fund 89, inventory 4, file 182. Typescript. (In Russian)

Stenograficheskiı̆ Otchet. 1930. Stenograficheskiu Otchet II s'ezda Soйuza Voinstvuiushchih Bezbozhnikov. Moscow: Bezbojnik. (In Russian)

Stroumsa, Guy G. 2010. A New Science: The Discovery of Religion in the Age of Reason. Cambridge: Harvard University Press.

Sukhova, Natalya. 2013. "Istoriko-bogoslovskaia revoliutsiia" v vyssheĭ duhovnoŭ shkole Rossii. Filaretovskiu sbornik 9: 135-69. (In Russian).

Taylor, Edward. 1939. Pervobytnaia Kul'tura. Moscow: Sotsegiz. (In Russian)

Tolz, Vera. 2011. Russia's Own Orient: The Politics of Identity and Oriental Studies in the Late Imperial and Early Soviet Periods. Oxford and New York: Oxford University Press.

Trubetskoi, Sergei. 1897. K bibliografii istorii religii. Voprosy Filosofii i Psihologii 1: 55-68. (In Russian).

Trudy Pervogo. 1932. Trudy Pervogo Vserossiǔskogo muzeynogo s'ezda, II. Moscow: Gosuchpedgiz. (In Russian)

Turaev, Boris. 1895. Zwei Hymnen an Thoth. Zeitschrift für Ägyptische Sprache und Altertumskunde 33: 120-25.

Zaborowski, Robert. 2009. Tadeusz Zieliński (1859-1944)—Sa vie et son œuvre. Annales du Centre Scientifique à Paris de l'Académie Polonaise des Sciences 12: 207-22.

Zhebelev, Sergei, and Nikolai Marr. 1919. Obrashchenie. Saint-Petersburg: Central State Archive of St. Petersburg (TsGA SPb). fund 7240, inventory 14, file 46. Typescript. (In Russian)

(C) 2020 by the author. Licensee MDPI, Basel, Switzerland. This article is an open access article distributed under the terms and conditions of the Creative Commons Attribution (CC BY) license (http://creativecommons.org/licenses/by/4.0/). 